\title{
Influence of Alumina Phases on the Molybdenum Adsorption Capacity and Chemical Stability for ${ }^{99} \mathrm{Mo} /{ }^{99 m} \mathrm{Tc}$ Generators Columns
}

\author{
Cecilia C. Guedes-Silva ${ }^{a *}$, Thiago dos Santos Ferreira ${ }^{a}$, Flávio M.S. Carvalho ${ }^{b}$, Carolina M. de Paula,
}

\section{Larissa Otubo ${ }^{a}$}

\author{
anstituto de Pesquisas Energéticas e Nucleares - IPEN, Comissão Nacional de Energia Nuclear - \\ CNEN, Av. Prof. Lineu Prestes, 2242, 05508-000 São Paulo, SP, Brazil \\ ${ }^{b}$ Instituto de Geociências - IGC, Universidade de São Paulo - USP, Rua do Lago, 562, 05508-080, São \\ Paulo - SP, Brazil
}

Received: September 17, 2015; Revised: April 20, 2016; Accepted: May 11, 2016

\begin{abstract}
Technetium-99m is the clinically most used radionuclide worldwide. Although many techniques can be applied to separate ${ }^{99} \mathrm{Mo}$ and ${ }^{99 \mathrm{~m}} \mathrm{Tc}$, the most commonly used method is the column chromatography with alumina as stationary phase. However, the alumina nowadays used has limited adsorption capacity of molybdate ions which implies the need to develop or improve materials to produce high specific activity generators. In this paper, alumina was obtained by a solid state method and heat treatments at different conditions. The powders had a microstructure with porous particles of $\gamma, \delta, \theta$ and $\alpha-\mathrm{Al}_{2} \mathrm{O}_{3}$ phases as well as specific surface area between 36 and $312 \mathrm{~m}^{2} \mathrm{~g}^{-1}$. Most interesting results were reached by powders calcined at $900^{\circ} \mathrm{C}$ for 5 hours which had high chemical stability and a molybdenum adsorption capacity of $92.45 \mathrm{mg}$ Mo per g alumina.
\end{abstract}

Keywords: alumina, ${ }^{99} \mathrm{Mo}{ }^{\rho 9 m} \mathrm{Tc}$ generator, chromatography

\section{Introduction}

${ }^{99 \mathrm{~m}} \mathrm{Tc}$ has been successfully used in several nuclear medicine applications, such as cardiology and oncology. The important position of ${ }^{99 \mathrm{~m}} \mathrm{Tc}$ is owing to its nuclear properties that make possible the ready availability of ${ }^{99 \mathrm{~m}} \mathrm{Tc}$ radiopharmaceuticals from generators based on the low decay of ${ }^{99}$ Mo to ${ }^{99 \mathrm{~m}} \mathrm{Tc}$ with short half-life (6 hours) ${ }^{1}$. As well as this, gamma rays with adequate power $(140 \mathrm{keV})$ for singlephoton emission computed tomography (SPECT) can be readily collimated, allowing better location and minimizing the whole body dose $\mathrm{e}^{2,3}$.

The parent radioisotope $\left({ }^{99} \mathrm{Mo}\right)$ can be produced by irradiation of ${ }^{235} \mathrm{U}$ with thermal or fast neutrons or by irradiation of metallic molybdenum or molybdenum oxide $\left(\mathrm{MoO}_{3}\right)$ with neutrons. In the first case, the ${ }^{99} \mathrm{Mo}$ is produced together with other fission products, requiring separation by different techniques. In the second case, little processing is required but only a small portion of ${ }^{98} \mathrm{Mo}$ is converted to ${ }^{99} \mathrm{Mo}^{4-6}$. Hence, the use of ${ }^{99} \mathrm{Mo}$ produced by irradiadion of molybdenum, in generator columns, limits the activity of ${ }^{99 \mathrm{~m}} \mathrm{Tc}$ eluates since ${ }^{99} \mathrm{Mo} /{ }^{99 \mathrm{~m}} \mathrm{Tc}$ generators are formed by chromatography in which ${ }^{99} \mathrm{MoO}_{4}{ }^{2-}$ is adsorbed on an alumina column ${ }^{7}$. In other words, to obtain generators with adequate specific activity, it is necessary to use molybdenum of high activity obtained by the ${ }^{235} \mathrm{U}$ fission.

Therefore, in order to use molybdenum produced by neutron activation in ${ }^{99} \mathrm{Mo} /{ }^{99 \mathrm{~m}} \mathrm{Tc}$ generators, the adsorbent material used in the column should be modified because alumina has an adsorption capacity limited to $20 \mathrm{mg}$ Mo per

*e-mail: cecilia.guedes@ipen.br g alumina. Many studies have been attempted to develop a material with better performance than alumina but many problems related to the synthesis and to some characteristics of the material have been found ${ }^{8-12}$. This study evaluates the influence of the different alumina phases on the molybdenum adsorption capacity and chemical stability in physiological saline in order to use in ${ }^{99} \mathrm{Mo} /{ }^{99 \mathrm{~m}} \mathrm{Tc}$ generators.

\section{Experimental Procedure}

\subsection{Materials}

The starting materials were aluminum nitrate nonahydrate P.A. (Dinâmica) and ammonium carbonate P.A. (Neon) ${ }^{13}$. The reactants, in the stoichiometric composition, were ground using a mortar, dried at $100^{\circ} \mathrm{C}$ for 24 hours and calcined in air at $700^{\circ} \mathrm{C}$ for 2 hours (AMS700-2h), $900^{\circ} \mathrm{C}$ for 5 hours (AMS900-5h) and $1000^{\circ} \mathrm{C}$ for 5 hours (AMS1000-5h).

The calcined powder was treated in a $0.5 \mathrm{M}$ hydrochloric acid solution for 24 hours under constant agitation at 480 $\mathrm{rpm}$, washed with distilled water, filtered and dried at $100^{\circ} \mathrm{C}$ for 24 hours.

\subsection{Physical measurements}

In order to determine the thermal events during the increase of temperature, thermal analysis (thermogravimetry, TG and differential scanning calorimetry, DSC) measurements were performed under air flow at a heating rate of $10^{\circ} \mathrm{C} /$ min up to $1000^{\circ} \mathrm{C}$. 
Each synthesized powder was analyzed by X-ray powder diffraction (Siemens D5000 diffractometer X-ray, radiation $\mathrm{CuK} \alpha$ ) to identify the crystalline alumina phases. Also, the specific surface area of the materials was determined using Micromeritics equipment and the equation of BrunauerEmmett-Teller (BET). The morphology and porosity of the powders were observed by scanning electron microscopy (Philips XL30 and Jeol JSM6701F microscopes).

\subsection{Evaluation of Molybdenum Absorption Capacity}

The molybdenum adsorption capacity was measured by stirring a suspension containing $0.1 \mathrm{~g}$ of the calcined powder and $30 \mathrm{ml}$ of ammonium molybdate solution (1 $\mathrm{mg} / \mathrm{ml}$ ) with a $\mathrm{pH}$ of 1.5 . After 30 minutes under stirring, the suspension was filtered and analyzed by ICP-OES to determine the Mo concentration.

\subsection{Chemical Stability Tests}

For chemical stability tests, chromatographic columns containing $4 \mathrm{~g}$ of material were conditioned with $250 \mathrm{ml}$ of $\mathrm{HCl}$ with $\mathrm{pH}$ of $1.5 .6 \mathrm{ml}$ of physiological saline solution was passed through the column and collected to determine the aluminum content by colorimetric assay using Chromoazurol $\mathrm{S}$ like indicator.

\section{Results and Discussion}

Thermal analyses of the dried uncalcined precursor are shown in Figure 1. The results show five endothermic peaks between 70 and $200^{\circ} \mathrm{C}$ related to $11.6 \mathrm{wt} . \%$ of water loss and the peak found at $297^{\circ} \mathrm{C}$ is due to the decomposition of ammonium nitrate with a $61 \%$ of mass loss. An exothermic event found at $310^{\circ} \mathrm{C}$ is related to the rapid release of gases due to the oxidation of ammonium nitrate ${ }^{14}$.

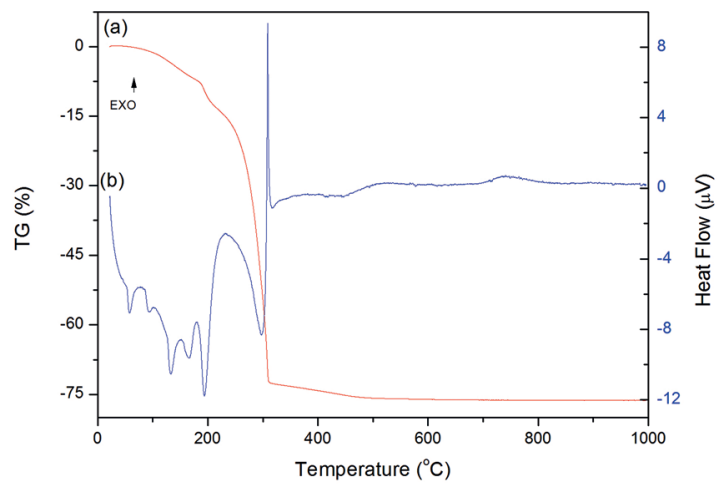

Figure 1: Thermal analysis of the material dried at $100^{\circ} \mathrm{C}$ for 24 hours: (a) TG and (b) DSC.

The evolution of the alumina phases for different heat treatments can be verified from powder diffraction patterns (Figure 2). Based on Figure 2, it is clear the dependence on polymorphic transformations in alumina with the temperature.

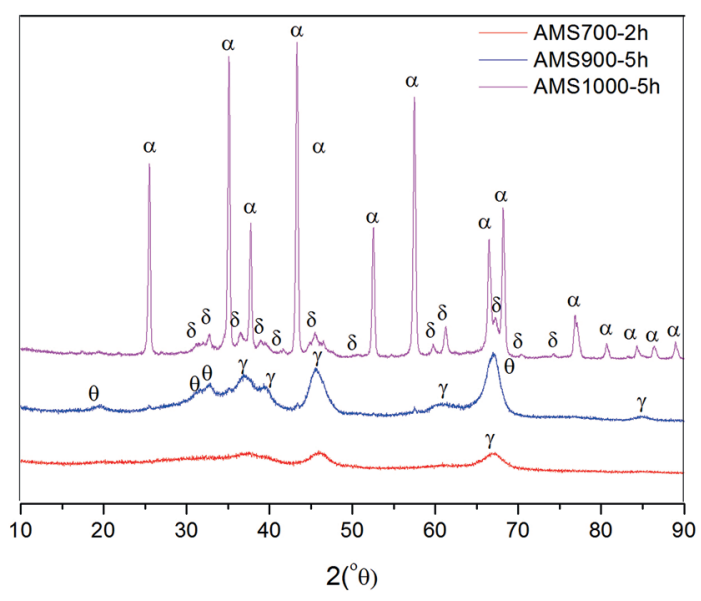

Figure 2: Powder diffraction patterns of the samples heat treated at $700{ }^{\circ} \mathrm{C} / 2 \mathrm{~h}, 900^{\circ} \mathrm{C} / 5 \mathrm{~h}$ and $1000^{\circ} \mathrm{C} / 5 \mathrm{~h}$.

The heat treatment performed at $700{ }^{\circ} \mathrm{C}$ for 2 hours was enough to transform the precursor to $\gamma-\mathrm{Al}_{2} \mathrm{O}_{3}$. Increasing the temperature and time to $900^{\circ} \mathrm{C}$ for 5 hours, we observed the presence of $\theta$ and $\gamma-\mathrm{Al}_{2} \mathrm{O}_{3}$ phases, while the treatments performed at $1000^{\circ} \mathrm{C}$ for 5 hours presented $\delta-\mathrm{Al}_{2} \mathrm{O}_{3}$ and $\alpha-\mathrm{Al}_{2} \mathrm{O}_{3}$ as transition and stable phases, respectively. The transition phases of alumina are considered advantageous to application as adsorbents in chromatography columns of ${ }^{99} \mathrm{Mo} /{ }^{99 \mathrm{~m}} \mathrm{Tc}$ generators due to the higher surface reactivity.

From data shown in Table 1, it is noted that the heat treatments carried out at lower temperatures resulted in powders with a larger specific surface area, suggesting that the transition alumina phases have higher reactivity. The material calcined at $1000^{\circ} \mathrm{C}$ for 5 hours, for example, had a value of specific surface area four times smaller than that calcined at $900^{\circ} \mathrm{C}$ for 5 hours due to the presence of $\alpha-\mathrm{Al}_{2} \mathrm{O}_{3}$ phase (Figure 2).

Table 1: Specific surface area (S) of the synthesized powders.

\begin{tabular}{lc}
\hline Sample & $\mathrm{S}\left(\mathrm{m}^{2} / \mathrm{g}\right)$ \\
\hline AMS700-2h & $312.0 \pm 2.0$ \\
AMS900-5h & $153.7 \pm 0.3$ \\
AMS1000-5h & $36.0 \pm 0.1$ \\
\hline
\end{tabular}

SEM images of the powders in Figure 3 show that the synthesis method results in highly porous powders, which corroborates with the high surface area determined by BET. Further analysis correlating the microstructure and the crystalline phase determined by XRD makes clear the effect of alumina phases on the surface's morphology and consequently on the surface area. From Figure 4, it is observed that the powder calcined at $900^{\circ} \mathrm{C} / 5 \mathrm{~h}$ (Figure 4a) shows a texturized morphology, typical of transition alumina phases. Powders calcined at $1000^{\circ} \mathrm{C} / 5 \mathrm{~h}$ (Figure $4 \mathrm{~b}$ ), although exhibit areas with similar texturized morphology, also contain some coalesced regions that can be attributed to $\alpha-\mathrm{Al}_{2} \mathrm{O}_{3}$ particles. The heat treatment performed at $1000^{\circ} \mathrm{C}$ for 5 hours led to material densification, noted by the lower porosity (Figure 4b), in agreement with the decrease in the surface area measured. 


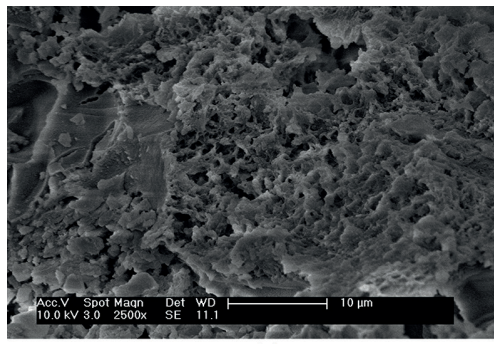

(a)

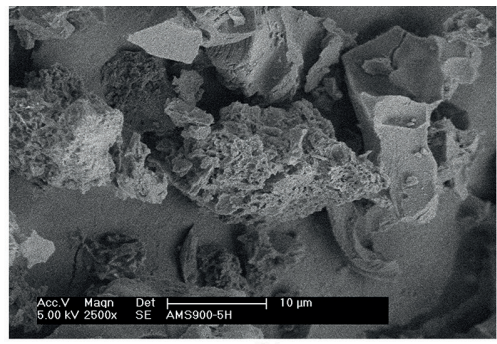

(b)

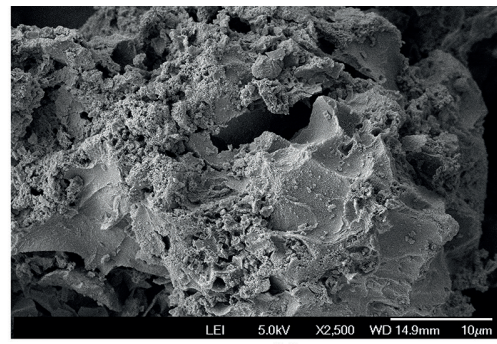

(c)

Figure 3: Scanning electron micrographs of powders synthesized at: (a) $700{ }^{\circ} \mathrm{C} / 2 \mathrm{~h}$, (b) $900{ }^{\circ} \mathrm{C} / 5 \mathrm{~h}$ and (c) $1000{ }^{\circ} \mathrm{C} / 5 \mathrm{~h}$.
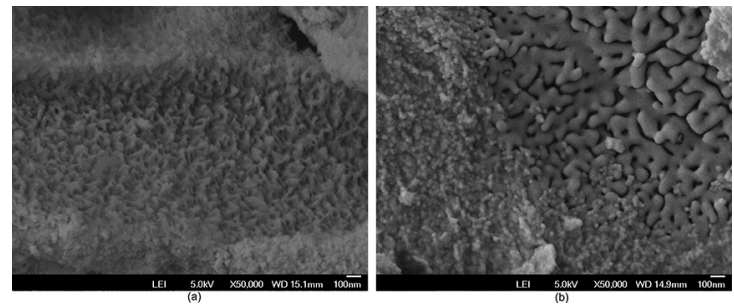

Figure 4: Micrographs obtained by field emission gun scanning electron microscope. Powders synthesized at: (a) $900^{\circ} \mathrm{C} / 5 \mathrm{~h}$ and (b) $1000^{\circ} \mathrm{C} / 5 \mathrm{~h}$.

In addition, the molybdenum absorption capacity of the powders (Table 2) was directly affected by their surface characteristics. The highest values achieved by materials calcined at $700^{\circ} \mathrm{C}$ for 2 hours are associated with the presence of gamma phase, high porosity and high specific surface area. While the lowest adsorption capacity was found for the calcined material at $1000^{\circ} \mathrm{C}$ for 5 hours due to the lower specific surface area and lower porosity resultant from the predominance of the $\alpha-\mathrm{Al}_{2} \mathrm{O}_{3}$ phase. Considering the studied powders, those treated at $900^{\circ} \mathrm{C}$ for 5 hours shown an intermediate adsorption capacity but the value was noteworthy $(92.45 \mathrm{mg} / \mathrm{g})$ compared with the limit of $20 \mathrm{mg} / \mathrm{g}$ reported for alumina currently used in ${ }^{99} \mathrm{Mo} /{ }^{99 \mathrm{~m}} \mathrm{Tc}$ generators.

Table 2: Molybdenum adsorption in the synthesized alumina.

\begin{tabular}{lc}
\hline Identification & $\mathrm{Mo}(\mathrm{mg}) / \mathrm{Al}_{2} \mathrm{O}_{3}(\mathrm{~g})$ \\
\hline AMS700-2h & 113.42 \\
AMS900-5h & 92.45 \\
AMS1000-5h & 37.11 \\
\hline
\end{tabular}

Table 3 presents the results of chemical stability tests that are of great importance for the proposed application because the elutions carried out to separate ${ }^{99 \mathrm{~m}} \mathrm{Tc}$ from ${ }^{99} \mathrm{Mo}$ use saline physiological solution as eluant. Data in Table 3 show that powders calcined at $700^{\circ} \mathrm{C}$ for 2 hours produced a solution with high aluminum content what evidences to be unsuitable for use in ${ }^{99} \mathrm{Mo} /{ }^{99 m} \mathrm{Tc}$ generator. Besides, this result indicates that the $\gamma-\mathrm{Al}_{2} \mathrm{O}_{3}$ phase has a higher solubility in physiological saline than the other phases of alumina. Chakravarty et al. ${ }^{13}$ obtained conflicting results since they found lower than $1 \mathrm{ppm}$ of aluminum when chemical stability tests were performed with acids and bases in powders calcined at $700^{\circ} \mathrm{C}$ for 2 hours.
Table 3: Content of aluminum present in the saline solution after chemical stability test.

\begin{tabular}{lc}
\hline Identification & $\mathrm{Al}(\mathrm{ppm})$ \\
\hline AMS700-2h & $17.5-25.0$ \\
AMS900-5h & $2.0-3.5$ \\
AMS1000-5h & $2.0-3.5$ \\
\hline
\end{tabular}

The presence of $\theta-\mathrm{Al}_{2} \mathrm{O}_{3}$ in the calcined material at $900^{\circ} \mathrm{C}$ for 5 hours was enough to reduce the solubility for levels lower than $2 \mathrm{ppm}$ of aluminum, identical to those found for the calcined material at $1000^{\circ} \mathrm{C}$ for 5 hours mainly constituted by $\alpha-\mathrm{Al}_{2} \mathrm{O}_{3}$. However, the low molybdenum absorption capacity of the powder treated at $1000^{\circ} \mathrm{C}$ for 5 hours turns impracticable its application for high activity ${ }^{99} \mathrm{Mo} /{ }^{99 m} \mathrm{Tc}$ generator columns.

\section{Conclusions}

The synthesis of alumina from the grind of aluminum nitrate and ammonium carbonate followed by drying and calcination can produce highly porous powders. The results showed that the temperature of calcination affected the alumina formed phases, microstructure, chemical stability and molybdenum adsorption capacity.

The heat treatment performed at $700^{\circ} \mathrm{C}$ for 2 hours promoted the formation of powder with $\gamma-\mathrm{Al}_{2} \mathrm{O}_{3}$ phase and textured morphology. These characteristics led to high specific surface, high molybdenum adsorption capacity but low chemical stability, making the material inappropriate for use in ${ }^{99} \mathrm{Mo} /{ }^{99 m} \mathrm{Tc}$ generators columns.

On the other hand, materials calcined at $1000^{\circ} \mathrm{C}$ for 5 hours had a great chemical stability but low values of surface specific area and molybdenum adsorption capacity because of the presence of the $\alpha-\mathrm{Al}_{2} \mathrm{O}_{3}$ phase and the lower porosity.

The best results were found for the powder calcined at $900^{\circ} \mathrm{C}$ for 5 hours. The presence of $\theta-\mathrm{Al}_{2} \mathrm{O}_{3}$ and $\gamma-\mathrm{Al}_{2} \mathrm{O}_{3}$ led to a relatively high surface area, high chemical stability and high molybdenum adsorption capacity making it promising to be applied as adsorbents in high activity ${ }^{99} \mathrm{Mo} /{ }^{19 m} \mathrm{Tc}$ generators columns.

\section{Acknowledgements}

The authors are highly grateful to Dr. Neuza Taeko Okasaki Fukumori and Dr. Margareth Mie Nakamura Matsuda for their help with ICP analysis. 


\section{Referências}

1. International Atomic Energy Agency. IAEA-TECDOC-852 Alternative technologies for ${ }^{99 \mathrm{~m}} \mathrm{Tc}$ generators. Vienna: International Atomic Energy Agency; 1995.

2. Allen JF. An improved technetium-99m generator for medical applications. The International Journal of Applied Radiation and Isotopes. 1965;16:332-334.

3. Molinski VJ. A review of ${ }^{99 \mathrm{~m}} \mathrm{Tc}$ generator technology. The International Journal of Applied Radiation and Isotopes. 1982;33(10):811-819.

4. Boyd RE. Technetium-99m generators-The available options. The International Journal of Applied Radiation and Isotopes. 1982;33(10):801-809.

5. Monroy-Guzman F, Rivero Gutiérrez T, López Malpica IZ, Hernández Cortes S, Rojas Nava P, Vazquez Maldonado JC, et al. Production optimization of ${ }^{99} \mathrm{Mo} /{ }^{99 \mathrm{~m}} \mathrm{Tc}$ zirconium molybdate gel generators at semi-automatic device: DISIGEG. Applied Radiation and Isotopes. 2012;70(1):103-111.

6. Seifert S, Wagner G, Eckardt A. Highly concentrated [ ${ }^{99 \mathrm{~m}} \mathrm{Tc}$ ] pertechnetate solutions from $(\mathrm{n}, \gamma){ }^{99} \mathrm{Mo} /{ }^{99 \mathrm{~m}} \mathrm{Tc}$ generators for nuclear medical use. Applied Radiation and Isotopes. 1994;45(5):577-579.

7. Lavi N. The study of conditions for the preparation and application of ${ }^{99} \mathrm{Mo}-{ }^{99 \mathrm{~m}} \mathrm{Tc}$ generators starting from irradiated molybdenum metal. Journal of Radioanalytical Chemistry. 1978;42(1):25-34.
8. Pinajian JJ. A technetium-99m generator using hydrous zirconium oxide. The International Journal of Applied Radiation and Isotopes. 1966;17(11-12):664.

9. Meloni S, Brandone A. A new technetium-99m generator using manganese dioxide. The International Journal of Applied Radiation and Isotopes. 1968;19(2):164-166.

10. Bigliocca C, Girardi F, Pauly J, Sabbioni E, Meloni S, Provasoli A. Radiochemical separations by adsorption on manganese dioxide. Analytical Chemistry. 1967;39(13):1634-1639.

11. El-Kolaly MT, Misak NZ. A ${ }^{99 \mathrm{~m}} \mathrm{Tc}$ Generator Based on the Adsorption of $\left[{ }^{99} \mathrm{Mo}\right]$ Molybdophosphate on hydrous manganese dioxide. International Journal of Radiation Applications and Instrumentation. Part B. Nuclear Medicine and Biology. 1988;15(4):459-461.

12. Mushtaq A, Mansoor MS, Karim HMA, Khan MA. Hydrated titanium dioxide as an adsorbent for ${ }^{99} \mathrm{Mo}-{ }^{99 m} \mathrm{Tc}$ generator. Journal of Radioanalytical and Nuclear Chemistry. 1991;147(2):257-261.

13. Chakravarty R, Ram R, Dash A, Pillai MRA. Preparation of clinical-scale ${ }^{99} \mathrm{Mo} /{ }^{99 m} \mathrm{Tc}$ column generator using neutron activated low specific activity ${ }^{99} \mathrm{Mo}$ and nanocrystalline $\gamma-\mathrm{Al}_{2} \mathrm{O}_{3}$ as column matrix. Nuclear Medicine and Biology. 2012;39(7):916-922.

14. Saber O. Novel self assembly behavior for $\gamma$-alumina nanoparticles. Particuology. 2012;10(6):744-750. 